\title{
Impact of indoor heating and overnight stagnation on tap water: Dynamics in water quality, biomass, bio-activity and bacterial community structure
}

Haihan Zhang ( $\nabla$ zhanghaihan@xauat.edu.cn)

Xi'an University of Arthitecture and Technology

Xiang Liu

Tinglin Huang

Ben Ma

Limin Niu

Kexin Zhao

Yuwei Huang

\section{Research Article}

Keywords: Bacterial community, Domestic drinking water, Network analysis, Structural equation model, 16S rRNA gene sequencing

Posted Date: February 11th, 2022

DOI: https://doi.org/10.21203/rs.3.rs-1331252/v1

License: (9) This work is licensed under a Creative Commons Attribution 4.0 International License. Read Full License 


\section{Abstract}

The drinking water distribution system is an important link with water supply system and it affects the quality of the drinking water. Indoor pipeline water quality is regulated by physical, hydraulic and biological elements, such as indoor temperature and stagnation. In this study, full-length 16S rRNA gene sequencing and flow cytometry were used to assess the indoor heating and overnight stagnation on the variation in bacterial community structure and the Intact cell count. The results exhibited that the average intact cell count was $6.99 \times 10^{4}$ cells $/ \mathrm{mL}$ and the low nucleic acid (LNA) bacteria was $4.48 \times 10^{4}$ cells $/ \mathrm{mL}$ after stagnation. The average concentration of total and intracellular adenosine triphosphate (ATP) was $3.64 \times 10^{-12} \mathrm{gATP} / \mathrm{mL}$ and $3.13 \times 10^{-17} \mathrm{gATP} /$ cell in stagnant water, respectively. The growth of LNA cells played a crucial role in increasing ATP. The dominant phylum was Proteobacteria with average abundance of $87.21 \%$, followed by Actinobacteria (8.25\%). Pseudomonas sp. and Mycobacterium sp. increased 1.2-fold and 5.8-fold in stagnant water. Structural equation model and redundancy analysis illustrated that temperature, residual chlorine and Fe concentration significantly affected bacterial count and bacterial community. Taking together, these results show responses of drinking water quality to overnight stagnation and indoor heating, and provide scientific basis for drinking water security management.

\section{Introduction}

The safety of the drinking water has been widely concerned due to increasing urbanization [1, 2]. The microbial ecology of the drinking water plays a critical role in a wide range of water management [3] and health problems [4]. For instance, the bacterial metabolism and propagation in the pipeline ecosystem will not only deteriorates the water quality, but also pose hazards to human health by opportunistic pathogens (OPPPs), such as Legionnella sp., Mycobacterium sp. and Pseudomonas sp. [5-7]. As the terminal system of drinking water distribution systems (DWDS), tap is a common way for residents to obtain drinking water in daily life. However, the bacterial community in tap water have not been adequately studied [7, 8], compared with that in drinking water reservoirs [9-11] and drinking water treatment plants [12] which are also the important determinant factors of drinking water quality.

As an important factor affecting pipeline water quality together with physical and hydraulic conditions, organisms have attracted extensive attention of researchers $[1,13]$. Previous studies have summarized that the induction factors of biological variations in pipeline include long-distance water transmission [14], water source switching [15], indoor environmental change [16] and stagnation [2, 17, 18]. Drinking water may linger for hours or even days before it is employed in pipeline, which can further lead to bacterial regrowth, especially combined with high ambient temperature [19]. In northern China, indoor temperature can reach up to $25^{\circ} \mathrm{C}$ for a long time through indoor heating [20]. Thus far, only a few of studies surveyed the comprehensive affection of stagnation on microbial community during wintertime in real DWDS [8]. Therefore, it is necessary to study the combined effect of indoor heating and stagnation on the microbial load and bacterial community in the pipes 
Molecular techniques represented by 16S rRNA gene sequencing have promoted the development of modern microbiology, which allow researchers to capture information about the evolution and diversity of microbes in the environment, bypassing the culture methods [21]. Compared with fragment 16S rRNA gene sequencing, the full-length 16S rRNA gene sequencing exhibit the advantages in presenting complete microbial community structure information, which have been widely used in all aspects of water bacteria detection [22, 23]. For example, Zhang et al. (2018) investigated the role of $V$ regions of different genes in bacterial diversity in eutrophic freshwater lakes by full-length 16S rRNA gene sequencing. Similarly, this method was also applied to reveal spatiotemporal dynamics of bacterial community in a heavily polluted estuary [23]. However, the adhibition of full-length 16S rRNA gene sequencing to detect bacteria community in tap water has rarely been reported.

Additionally, recent publications have suggested that the application of flow cytometry (FCM) to the cell quantitative analysis of aquatic microorganisms [24-26]. Interestingly, the stained cells by FCM are clearly divided into two categories: high nucleic acid (HNA) cells and low nucleic acid (LNA) cells [27]. A previous study has considered that LNA bacteria are active [28] and as compared with HNA bacteria, the special membrane structure and protein metabolism resistance mechanism of LNA bacteria enable it to be more adaptable to certain external environmental pressures, like low nutrient environment [29]. The intracellular ATP concentration of HNA cells was $15.5 \times 10^{-17} \mathrm{gATP} /$ cell, while that of LNA cells was $1.2 \times$ $10^{-17}-3.2 \times 10^{-17}$ gATP/cell [30]. Ahmad et al. [31] studied that temperature increase induced by thermal energy recovery in DWDS led 6-fold higher adenosine triphosphate (ATP) concentration and 2-fold higher HNA cell counts in the effluent water. However, changes in LNA bacteria and HNA bacteria have been neglected in drinking water studies $[8,17,26]$. Through the analysis of the variation in LNA bacteria and HNA bacteria counts caused by overnight stagnation could expand our knowledge on the bacterial regrowth in DWDS.

In this study, to explore the comprehensive effect of municipal heating on water quality and bacterial regrowth of indoor drinking water pipe, water samples were collected from five different constructions distributed in a city at northwest China (Xi'an) to determine the variations of water quality, bacterial abundance and community structure in tap water after overnight stagnation during winter season. Therefore, the specific assignments were: $(\nabla)$ to evaluate the effect of overnight stagnation on chemical water quality parameters under indoor heating; (ii) to determine the dynamic changes in bacterial proliferation during indoor heating; ( $\nabla$ ) to examine the changes of bacterial community structure before and after stagnation by full-length $16 \mathrm{~S}$ rRNA gene sequencing. Meanwhile, these results could provide a more comprehensive understanding of static tap water quality and increase our scientific knowledge to maintain the safety of tap water.

\section{Materials And Methods}

\subsection{Sample collection}


This study was conducted in Xi'an City, China $\left(33^{\circ} 25^{\prime}-34^{\circ} 27^{\prime} \mathrm{N}, 107^{\circ} 240^{\prime}-109^{\circ} 29^{\prime} \mathrm{E}\right)$ in December 2020. Indoor heating is widely used in northern cities of China during the winter season, which maintains indoor temperature at $25^{\circ} \mathrm{C}$. Tap water samples were collected at five different sampling sites, which have direct water supply system with normal functioning municipal heating, including laboratories (HG), toilets (YF), residential apartments (SS and YGC) and offices (BG). Galvanized iron pipes are applied in all sampled sites. The iron faucets are equipped in SS and BG, while stainless-steel faucets are equipped in $\mathrm{HG}, \mathrm{YF}$ and YGC. All sampling sites were supplied with water from a drinking water reservoir and used chlorine as a disinfectant. Water samples were collected at each sampling site once.

Prior to the sampling, the rooms were closed and taps were closed for 7 hours to stabilize the room temperature. During the sampling process, $1.5 \mathrm{~L}$ of tap water (labeled as stagnation) from each sampling site was collected in sterilized glass bottles. After flushing for 10 minutes, the water temperature dropped sharply and then $1.5 \mathrm{~L}$ of water (labeled as fresh) was collected [32,33]. These samples were immediately transferred to the lab and preserved. Stagnant and fresh water samples were used to determine the chemical water quality, bacterial count, and bacterial diversity [17].

\subsection{Water quality parameters}

To estimate the water quality parameters of stagnant and fresh water samples, the thermometer and $\mathrm{pH}$ meter (Hach, USA) was carried out to measure the water temperature and $\mathrm{pH}$. The concentrations of residual chlorine, ammonia $\left(\mathrm{NH}_{4}{ }^{+}-\mathrm{N}\right)$, nitrate $\left(\mathrm{NO}_{3}{ }^{-} \mathrm{N}\right)$ and total phosphorus (TP) were examined by spectrophotometry (UNICO, USA) according to the procedures described in an early study [8]. The contents of total organic carbon (TOC) and total iron were estimated by a TOC analyzer (Shimadzu, Japan) and an atomic absorption spectroscopy (Shimadzu, Japan), respectively.

\subsection{Biomass and bio-activity}

To detect the biomass in water samples, FCM measurements were adopted. The intact cell counts (ICC) were determined by using FCM as the methods described in a previous study by Zhang et al [8]. Briefly, ICC were determined by a BD Accuri C6 flow cytometer (NJ, USA) and SYBR Green I ( $10 \mu \mathrm{L} / \mathrm{mL}$, Invitrogen, USA). The water samples were mixed with SYBR Green I by a vortex oscillator (DHS, China). The mixtures were then stained in a DHB-SMART metal heating (DHS, China) at $30^{\circ} \mathrm{C}$ for $20 \mathrm{~min}$. And then the green fluorescence signal of FL1 channel was set to $520 \pm 20 \mathrm{~nm}$. The identical FL1 signaling thresholds were selected to estimate LNA and HNA cell concentrations in water samples and the LNA\% as the ratio of between LNA cells and ICC were calculated [34].

To analyze the bacterial activity of stagnant and fresh samples, the contents of ATP were detected by a luminometer (Promega, USA) and Bac-Titer-Glo ${ }^{\text {TM }}$ reagent (Promega, USA) [35]. Briefly, water samples (500 $\mu \mathrm{L})$ and ATP reagent $(50 \mu \mathrm{L})$ were heated in a thermostatic metal bath (DHS, China) at $38^{\circ} \mathrm{C}$ for $10 \mathrm{~min}$ and 2 min under the condition of avoiding light respectively. After mixed, samples were heated immediately for $20 \mathrm{~s}$ to measure the luminescence intensity. The water samples were passed through a 0.1 - um sterile filter (Heaion, China) to extract the extracellular ATP. 


\subsection{DNA extraction and bacterial community structure}

To investigate the special composition of bacteria community in the taps water, full-length 16S rRNA gene sequencing was carried out in this study. One liter of each water sample was filtered on $0.22-\mu \mathrm{m}$ membrane filter (Jinteng, China) and the genomic DNA was extracted using E.Z.N.A.® Soil DNA Kit (Omega Bio-tek, USA). The bacterial 16S rRNA genes were amplified by PCR using the primer sets $27 \mathrm{~F} 5^{\prime}$ AGRGTTYGATYMTGGCTCAG - $3^{\prime}$ and 1492R 5' - RGYTACCTTGTTACGACTT - 3 ' by the procedure: $95^{\circ} \mathrm{C}$ for $2 \mathrm{~min}$, followed by 27 cycles at $95^{\circ} \mathrm{C}$ for $30 \mathrm{~s}, 55^{\circ} \mathrm{C}$ for $30 \mathrm{~s}$, and $72^{\circ} \mathrm{C}$ for $60 \mathrm{~s}$ and a final extension at $72^{\circ} \mathrm{C}$ for $5 \mathrm{~min}$. The PCR reaction was taken in triplicate mixtures consisted by $4 \mu \mathrm{L}$ of $5 \times \mathrm{FastPfu}$ Buffer, $2 \mu \mathrm{L}$ of $2.5 \mathrm{~mm}$ Deoxyribonucleotide Triphosphates, $0.8 \mu \mathrm{L}$ of each primer $(5 \mu \mathrm{m}), 0.4 \mu \mathrm{L}$ of FastPfu Polymerase, and $10 \mathrm{ng}$ of template DNA. Afterwards, the AxyPrep DNA Gel Extraction Kit (Axygen Biosciences, USA) was utilized to extract and purify amplicons from $2 \%$ agarose gels according to the manufacturer's instructions $[22,36]$. The sequencing was done at the BIOZERON biotechnology Co., Ltd. (Shanghai, China).

To organize the data of Operational Taxonomic Units (OTUs), UPARSE (version 7.1 http://drive5.com/uparse/) was conducted to cluster the OTUs with $97 \%$ similarity and UCHIME was employed to identify the sequences date. Uclust algorithm (http://www.drive5.com/usearch/manual/uclust_algo.html) was applied to analyze the phylogenetic relationships among the 16S rRNA gene sequences in Silva (SSU138.1) database at $80 \%$ confidence threshold. The Alpha diversity were analyzed by using Mothur v.1.21.1. The data was put on record at the NCBI database (http://www.ncbi.nlm.nih.gov/), with the access number of PRJNA 756799.

\subsection{Statistical analysis}

To compare the differences between fresh and stagnant water, $t$-test was adopted with IBM SPSS statistics 25. The histogram or box plot of ATP contents and ICC were plotted by Origin 2019 software. To verify the form of the taxon abundance distribution in the stagnant water and fresh water, species abundance distribution (SAD) model was constituted by using R software (version 3.6.1) with the vegan package [37]. To analyze the correlation between the bacterial communities, redundancy analysis (RDA) and co-occurrence network analysis was generated with CANOCO (version 4.5) and R software (version 3.6.1), respectively $[8,38]$.

The relationship among the temperature, environmental factors $\left(\mathrm{pH}\right.$, residual chlorine, $\mathrm{NO}_{3}{ }^{-} \mathrm{N}_{1} \mathrm{NH}_{4}{ }^{+}-\mathrm{N}, \mathrm{TP}$, Fe and TOC), bacterial cell counts and bacterial community structure, structural equation modeling (SEM) was built by using R software (version 3.6.1) with the lavaan package $[18,39]$. The $\chi^{2}$-test was utilized to examine Goodness-of-fit for SEM.

\section{Results And Discussion}

\subsection{Variation of water quality parameters}


As shown in Table 1, the temperature range of the stagnant water was $11.3-17.9^{\circ} \mathrm{C}$ and the fresh water was $8.2-11.4^{\circ} \mathrm{C}$. The temperature of water samples increased significantly after stagnation $(P<0.001)$. The $\mathrm{pH}$ value of stagnant water was not significantly different $(P>0.05)$ from that of fresh water. After stagnation, the $\mathrm{pH}$ value was also within the normal range specified in the official Chinese standards for drinking water quality (GB 5749-2006). The results obtained in this study was similar to the observation made by Zhang et al. [19], in which the temperature of the stagnant overnight water conducted range from 15 to $17^{\circ} \mathrm{C}$, and the temperature of the fresh water dropped to $4-6^{\circ} \mathrm{C}$ after 10 -minute flush in winter season.

Table 1

Water quality parameters of stagnant and fresh water in winter season.

\begin{tabular}{|c|c|c|c|}
\hline Water quality & Stagnation & Fresh & t-test \\
\hline $\mathrm{T}\left({ }^{\circ} \mathrm{C}\right)$ & $13.84 \pm 1.50$ & $10.26 \pm 0.76$ & $\star \star \star$ \\
\hline $\mathrm{pH}$ & $7.79 \pm 0.24$ & $7.75 \pm 0.19$ & NS \\
\hline Free residual chlorine $(\mathrm{mg} / \mathrm{L})$ & ND & $0.18 \pm 0.05$ & NS \\
\hline Total residual chlorine $(\mathrm{mg} / \mathrm{L})$ & $0.10 \pm 0.01$ & $0.26 \pm 0.02$ & 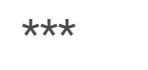 \\
\hline $\mathrm{NO}_{3}{ }^{-}-\mathrm{N}(\mathrm{mg} / \mathrm{L})$ & $1.71 \pm 0.16$ & $1.86 \pm 0.16$ & ** \\
\hline $\mathrm{NH}_{4}{ }^{+}-\mathrm{N}(\mathrm{mg} / \mathrm{L})$ & $0.06 \pm 0.02$ & $0.07 \pm 0.02$ & NS \\
\hline $\mathrm{TP}(\mathrm{mg} / \mathrm{L})$ & $0.02 \pm 0.01$ & $0.02 \pm 0.01$ & NS \\
\hline $\mathrm{TOC}(\mathrm{mg} / \mathrm{L})$ & $1.45 \pm 0.02$ & $1.51 \pm 0.03$ & * \\
\hline $\mathrm{Fe}(\mathrm{mg} / \mathrm{L})$ & $0.11 \pm 0.05$ & $0.02 \pm 0.01$ & $\star \star$ \\
\hline
\end{tabular}

Residual chlorine is one of the most common indicators that affects water quality and bacterial community structure in drinking water. As shown in Table 1, the concentration of total and free residual chlorine decreased significantly after stagnation $(P<0.001)$. The total residual chlorine concentrations decreased by $48.22-65.07 \%$ after stagnation and the free residual chlorine concentrations were below the detection limit in the stagnant water samples. These results were consistent with a previous study [40], which indicated that lower $\mathrm{pH}$ and higher temperature accelerated the chlorine decay rate in copper pipes. Under the condition of stagnation, the residual chlorine decayed over time due to the consumption of microorganisms, organic matter and invasive material [41].

The $t$-tests showed that there were no significant differences in the $\mathrm{NH}_{4}{ }^{+} \mathrm{N}$ and TP concentrations before and after flushing $(P>0.05)$ (Table 1). In contrast, the concentrations of $\mathrm{NO}_{3}{ }^{-} \mathrm{-N}, \mathrm{Fe}$ and TOC differed significantly $(P<0.05)$. Briefly, the average contents of $\mathrm{NO}_{3}{ }^{-}-\mathrm{N}$ was reduced by $6.1 \%$ after stagnation. 
This result was contrary to the findings presented by Masters et al. [42], which found the concentration of $\mathrm{NO}_{3}{ }^{-}-\mathrm{N}$ increased when the stagnant time was less than 1 day in their study. Masters et al. [42] also found that facultative denitrifying bacteria (measured by the abundance of denitrifying gene) were ubiquitous in drinking water pipes and the gene abundance increased with water age. Autotrophic denitrifying bacteria utilized $\mathrm{H}_{2}$ produced by iron as electron donor and nitrate as electron acceptor to convert $\mathrm{NO}_{3}{ }^{-}-\mathrm{N}$ to $\mathrm{N}_{2}$ under a water environment with metal iron, which might be responsible for the reduction of $\mathrm{NO}_{3}{ }^{-} \mathrm{N}$ content. At the same time, this reaction might cause the rise in $\mathrm{pH}$ value and induce iron corrosion.

As shown in Table 1, the average concentration of Fe in the stagnant water samples $(0.11 \mathrm{mg} / \mathrm{L})$ was 4.43-fold higher than that of fresh water samples $(0.02 \mathrm{mg} / \mathrm{L})$. Iron was released from the pipe into the water during stagnation. This conclusion was similar to the results observed by Tian et al. [4], in which the stagnant time was found to be an essential influencing factor for the release of Fe. However, only long periods of stagnation ( $>8 \mathrm{~h}$ ) may cause considerable risk and risk associated with overnight stagnation is considerably low. According to previous researches, water quality factors such as chloride, dissolved organic matter and $\mathrm{pH}$ would affect the stability of Fe in the pipeline [43-45]. Their studies disclosed that chloride was deemed to increase Fe concentration in DWDS. On the contrary, the increasing of $\mathrm{pH}$ was proved to enhance the Fe stability and reduce the Fe release in actual distribution systems.

As an indispensable element for bacterial regrowth in DWDS, trace amount of organic carbon $(1 \mu \mathrm{g} / \mathrm{L})$ could support up to $10^{3}-10^{4}$ cell/mL microbes to reproduce $[17,46]$. The average TOC concentration of fresh water $(1.51 \mathrm{mg} / \mathrm{L})$ was generally higher than that of stagnation $(1.45 \mathrm{mg} / \mathrm{L})$ in this study. A previous study also observed downtrends in TOC content with increased stagnation time, and the $30 \%$ reduction was examined after 168-hour of stagnation in the TOC concentrations [17]. Moreover, organic matter was known to serve as precursors for disinfection byproducts, and the presence of organic matters supplement increased the level of free chlorine residual required to control the microorganisms [47].

\subsection{Changes in biomass and bio-activity}

As "the energy currency" of biological cells, ATP was used to evaluate the bacterial activity. Fig. 1a, b displayed a higher concentration of ATP before flushing $(P<0.05)$. The concentration of total ATP and intracellular ATP increased by 1.65 and 1.69 times after stagnation, respectively. Series of studies also found that ATP increased after overnight stagnation [31,34], which probably due to the suitability of indoor temperature for bacterial regeneration in the pipelines. In addition, the enhancement in metabolic activity and reproductive capacity of the cells in the stagnant samples were expressed by increasing intracellular ATP which is consistent with conclusions made in a recent study [8]. However, the intracellular ATP concentration per cell in stagnant water was lower than that measured by Zhang et al. [8], which might be due to the affection of temperature and the proportion of LNA cells to total cell count.

Wang et al. [30] compared the growth rate of LNA bacteria at $12,20,25$ and $30^{\circ} \mathrm{C}$, and the results showed 
that the growth rate of LNA bacteria was the highest at $30^{\circ} \mathrm{C}$. Meanwhile, ATP concentration of LNA bacteria increased continuously during the stagnation process.

As shown in Fig. 1C and Supplementary Figure 1, ICC was significantly higher after stagnation $(P<$ 0.001 ). The average intact cell count in stagnant water was $6.99 \times 10^{4}$ cells $/ \mathrm{mL}$ (range $=3.96-12.31 \times$ $10^{4}$ cells $\left./ \mathrm{mL}\right)$, which was 1.53 -fold as much as that in fresh water $\left(2.44 \times 10^{4}\right.$ cells $\left./ \mathrm{mL}\right)$. These results were consistent with those conducted in previous studies $[17,48,49]$. The increasing ICC might be due to the variations of in the water environment in taps during indoor heating, including higher temperature and lower chlorine content [48]. Moreover, the free chlorine concentration was also an important factor limiting the number of bacteria, and the low chlorine concentration at the end of the faucet created favorable conditions for bacterial regeneration [17]. Furthermore, the release of biofilms was also an important source of bacteria. Ling et al. [49] found that the communities of water sampled in taps were more similar to that in biofilms than that in pipeline water. At the same time, the scour effect caused by the change of hydraulic conditions during the sampling process triggered the transportation of bacteria from the biofilm and pipe sediments to the water [1]. In general, the combination of the water environment, biofilm release, and scour effect caused the higher ICC in stagnation samples.

LNA bacteria could adopt dormancy strategy to deal with adverse environmental conditions [28]. LNA bacteria have higher survival competitiveness than HNA bacteria in oligotrophic environment, and become the dominant bacteria in the environment. Supplementary Figure 2 indicated the FCM graph of LNA and HNA cells. The percentage of LNA cells in the Intact cell counts (LNA\%) is shown in Fig. 1d. The number of LNA cells in stagnant water samples (range $=1.53-4.38 \times 10^{4}$ cells $/ \mathrm{mL}$ ) increased significantly compared with that in fresh water samples (range $=1.24-2.11 \times 10^{4}$ cells $/ \mathrm{mL}$ ). However, LNA\% in stagnant water (range $=24.29 \%-48.48 \%$ ) samples presented a downward trend compared with that in fresh water samples (range $=41.08 \%-67.88 \%$ ). The increase in LNA and HNA bacteria during stagnation was agreed with the results observed by Zlatanović et al. [17]. Gabrielli et al. [34] also found that LNA\% generally decreased during night (due to a higher utilization of nutrients was conducive to the growth of HNA bacteria and/or the passage from LNA to HNA).

In addition to the relationship between HNA/LNA bacteria and ATP concentration, Wang et al. [25] indicated that increased counts of HNA cells might be associated with a 4-fold increase in ATP concentration. The transfer of LNA cells to HNA cells could account for a slight increase of ATP concentrations of stagnation. The conclusion was consistent with a previous study by Liu et al. [26], which reported that ATP-per-cell content of HNA cells were 10-fold higher than the LNA cells.

\subsection{Bacterial community structure}

Through the sequencing, 205,760 reads were detected from the stagnant water samples $(11,165$ to 45,878 reads per sample) and the fresh water samples (10,924 to 40,003 reads per sample). As shown in Supplementary Table 1, the mean length of clean reads was $1374 \mathrm{bp}$, and the length of clean reads were obtained from the stagnant water ranged from 1313 to $1400.71 \mathrm{bp}$ per sample and in fresh water 
samples from1302.64 to $1401.16 \mathrm{bp}$ per sample). It is worth noting that the sequence number mainly focused on sequencing ranged from 1401 to $1500 \mathrm{bp}$.

In total, 34,960 and 34,955 OTUs were produced in the fresh and stagnant water samples, respectively (Table 2). The average OTUs number in stagnant water was 227 (range $=183-280$ ), which was slightly higher than OTUs observed for freshwater samples $(218$; range $=199-236)$. A previous reported found that the average OTUs number was 449 per sample in stagnant water, and 323 per sample in fresh water (8). The low number of OTUs observed in the present study, possibly due to the full-length sequencing with clearer bacterial information and made the clustering more explicit.

Table 2

Bacterial community richness and diversity indices in each stagnant and fresh water sample.

\begin{tabular}{|c|c|c|c|c|c|}
\hline \multirow[t]{2}{*}{ Simple ID } & \multicolumn{5}{|c|}{0.97 level } \\
\hline & OTUs & Chao 1 & Coverage & Shannon & Simpson \\
\hline HG-S & 280 & $319(298,364)$ & 0.999 & $3.74(3.72,3.76)$ & $0.0582(0.0568,0.0596)$ \\
\hline $\mathrm{HG}-\mathrm{F}$ & 214 & $240(226,274)$ & 0.997 & $3.70(3.67,3.73)$ & $0.0459(0.0472,0.0506)$ \\
\hline YF-S & 228 & $265(244,313)$ & 0.996 & $3.83(3.80,3.86)$ & $0.0435(0.0422,0.0448)$ \\
\hline YF-F & 233 & $264(248,298)$ & 0.994 & $3.64(3.60,3.67)$ & $0.0621(0.0597,0.0645)$ \\
\hline SS-S & 183 & $294(273,336)$ & 0.998 & $3.04(3.05,3.06)$ & $0.1330(0.1304,0.1357)$ \\
\hline SS-F & 199 & $321(287,364)$ & 0.998 & $2.90(2.88,2.92)$ & $0.1511(0.1484,0.1538)$ \\
\hline YGC-S & 218 & $260(239,303)$ & 0.993 & $3.51(3.47,3.55)$ & $0.0716(0.0687,0.0745)$ \\
\hline YGC-F & 210 & $258(236,304)$ & 0.995 & $3.06(3.02,3.10)$ & $0.1353(0.1305,0.1401)$ \\
\hline BG-S & 225 & $262(246,296)$ & 0.994 & $3.87(3.84,3.90)$ & $0.0427(0.0410,0.0444)$ \\
\hline BG-F & 236 & $293(265,350)$ & 0.993 & $3.81(3.77,3.84)$ & $0.0442(0.0427,0.0506)$ \\
\hline
\end{tabular}

Table 2 exhibits Chao 1, Shannon and Simpson indices obtained for the stagnant and fresh water samples. The OTUs values of the bacterial communities were all lower than the Chao 1 richness index, indicating that there were many unknown bacterial sequences in DWDS (50). Moreover, greater richness and diversity was discovered after stagnation due to higher alpha diversity [18, 51].

As shown in Fig. 2a, the dominant phylum in all water samples was Proteobacteria which accounted for $87.21 \pm 6.54 \%$ of the classified sequences, followed by Actinobacteria ( $8.25 \pm 4.55 \%)$. Higher abundance of Proteobacteria in the stagnant water samples $(87.94 \pm 5.80 \%)$ was observed as compared to the fresh water samples $(86.47 \pm 6.16 \%)$. Approximate results were obtained in DWDS by Zhang et al. [8] and Ling et al. [49], which presented that the OTUs related to Proteobacteria, Actinobacteria, and Bacteroidetes became more abundant after stagnation. 
The dominant bacterial genera observed in the stagnant and fresh water samples are shown in Fig. $2 \mathrm{~b}$. Obvious changes in the bacterial community structure were observed after stagnation. In fresh water samples, the number of OTUs assigned to Curvibactersp., Mesorhizobium sp. and Methylovirgula sp. were higher i.e., $25.42 \pm 13.63 \%$ vs $36.68 \pm 26.38 \%, 2.38 \pm 1.33 \%$ vs $4.19 \pm 2.37 \%$ and $1.84 \pm 0.94 \%$ vs $2.89 \pm 0.81 \%$, respectively. Ralstonia sp., Acinetobactersp. and Phreatobactersp. became more abundant after stagnation, i.e., $17.09 \pm 13.69 \%$ vs $11.55 \pm 8.34 \%, 4.10 \pm 3.76 \%$ vs $0.03 \pm 0.00 \%$ and $3.55 \pm 5.03 \%$ vs $2.43 \pm 1.76 \%$, respectively (Supplementary Figure 3 ). The OTUs number with increased abundance at the species level is shown in Supplementary Figure 4. Furuhata et al. [52] found that Ralstonia sp. was the most dominant bacteria in cold water samples from water dispensers, which also presented in healthy human bodies and widely distributed in the upper respiratory tract, such as the oral cavity, pharynx and trachea. Meanwhile, earlier research has referred that it was very rare for a healthy person to develop an infection caused by these bacteria, but for those people with an immune deficiency or reduced resistance might develop respiratory infections or blood poisoning due to Ralstonia sp. [53]. In addition, Acinetobactersp. was a common species in tap water and it became the dominant bacteria when the stagnant time reached $12 \mathrm{~h}$ [54]. With its increasing antibiotic tolerance and its potential risk leading to hospital infections, natural disaster-related infections and community-acquired infections, Acinetobacter sp. had become an issue of major public health [55]. Furthermore, Perrin et al. [56] found that the relative abundance of Phreatobactersp. was significantly higher during warmer period. A relevant report indicated that the abundance of Phreatobactersp. was negatively associated with the content of chlorine in water bodies [57]. The abundance of Phreatobacter sp. in stagnant water might be caused by biofilm release [58].

As shown in Supplementary Figure 3, the abundance of Pseudomonas sp. and Mycobacterium sp. increased after overnight stagnation, i.e., $120.08 \%$ and $585.71 \%$ higher, respectively. This result was consistent with the previous reports $[5,8,59]$ in which they indicated that the abilities of Mycobacteria sp. and other OPPPs to persist and survive in the pipeline environment were attributed to the ability of biofilms formation, the relative resistance to disinfectant, and the strong adaptability to oligotrophic conditions. More importantly, the pathogen communities could cause waterborne diseases such as pneumonia, sepsis and infection $[55,60]$. Thus, more attention should be paid to these microbes.

AIC index was used to explain the fitting of the abundance distribution models of several theoretical taxa to stagnant and fresh water data [37]. As shown in Fig. 3, the lognormal model was both fit for stagnant water $(\mathrm{AIC}=6213.95)$ and fresh water $(\mathrm{AIC}=5794.42)$. A recent study confirmed the conclusion, which indicated that the global distribution of abundance in microbial communities was lognormal [61]. The lognormal model represents a distribution in which both extremely abundant and extremely rare species have small proportions [62]. The community dynamics presented by the lognormal model is a random zero-sum process, which indicate that the death or migration of one individual in a community is immediately followed by the emergence of another random individual to fill the vacancy [63]. Since only a few species dominate, the species abundance distribution of drinking water might be determined by ecological niche. 
As a neo-analytical method, network analysis is generally used to study the interactions of microbemicrobe and microbe-environment interactions in complicated ecological systems $[10,64]$. The different networks containing bacterial communities at genus were analyzed and presented in Fig. $4(|r|>0.6, P<$ 0.05). The topological properties of networks are presented in Supplementary Table 2. As shown in Fig. 4, 108 edges were calculated $(76.11 \%$ positive and $23.89 \%$ negative) for bacteria in stagnant water samples, and 112 edges ( $73.15 \%$ positive and $26.85 \%$ negative) for bacteria in fresh water samples. This conclusion revealed that the interaction with respect to symbiosis, coaggregation, and cocolonization among microorganisms was more abundant in the drinking water pipeline ecosystem [38]. Compared with fresh water, the average path length of stagnant water was lower, which illustrated microorganisms in stagnant water possessed the stronger ability of material exchange and energy transfer [65]. In addition, compared with fresh water ( 6 modules), the number of modules increased after stagnation (8 modules), which indicated that the survival modes of bacterial communities were more complicate after stagnation [10].

Node microorganisms with a large number of connections were critical in influencing the structure and function of the microbial community in water system. The bacterial interactions varied obviously after stagnation. The nodes with the greatest connections in fresh water were Phreatobacter sp., Variovorax sp. and Tsukamurella sp., but the key nods were Chitinophaga sp. and Mesorhizobium sp. in stagnant water. Previous studies informed that Chitinophaga sp. and Mesorhizobium sp. were commonly isolated from soil and plants which were proved to affect the survival of other microorganisms. The chitinolytic activity of Chitinophaga sp. might antagonize a range of aquatic microorganisms [66]. Krick et al. [67] investigated a marine Mesorhizobium sp. and reported the presence of several $\mathrm{N}$-acyl homoserine lactones (NAHLs). The bacteria reported to use AHLs for signal transmission between genera with certain antibacterial and cytotoxic activities. Chitinophaga sp. and Mesorhizobium sp. were not most abundant but played a crucial role in interspecific regulation of bacteria. However, the interspecies influence of bacteria in the stagnant water remains to be further studied, although some supporting results have been achieved in this study.

\subsection{Correlation analysis}

SEM was obtained to identify the interrelation between water quality and microorganisms (Fig. 5). Temperature had an effect on bacterial community structure (std. coeff $=0.14, P<0.05$ ), biomass (std. coeff $=0.17$ ), and environmental factors (std. coeff $=-0.54, P<0.001$ ) in all water samples. This result indicated that temperature might be the potential factor for the variations of bacterial community and ICC observed. This is in consistent with the result of a previous study by Zlatanović et al. [17], in which temperature was reported as one of the crucial controlling factors on growth and reproduction had been proved to occur an effective interrelation with bacterial counts and bacterial community structure in different ecosystems.

Other environmental factors were significant negatively correlated with the bacterial community structure (std. coeff $=-0.16)$ and bacterial cell count (std. coeff $=-0.40, P<0.05$ ). Nevertheless, the bacterial cell 
count was positively correlated with the bacterial community structure (std. coeff $=0.08$ ) and this is in agreement with the finding of Zhang et al. [18], which reportrd that stagnation was not only induced the number of bacteria cells, but also enriched the diversity of bacterial community structure.

RDA analysis was conducted to determine the characteristic environmental elements affecting the bacterial community at the genus level. RDA1 and RDA2 accounted for $41.2 \%$ and $15.6 \%$ of the total variation in Fig. 6 , respectively $(P<0.05)$. Moreover, temperature was considered as the most significant explanatory variable. In addition, RDA results showed the obvious clustering between stagnant and fresh water, indicating the significant differences in bacterial community structures between stagnant and fresh water.

The RDA results exhibited that the bacterial community structure was significantly influenced by temperature, which was consistent with the result observed by Zhang et al [18] and it was similar to the SEM results presented. Furthermore, chlorine and Fe concentrations also strongly influenced the bacterial community and this is in agreement with Baron et al. [6], which indicated that the abundance of OPPPs and denitrifying bacteria increased during the decay of chlorine. Similarly, Ji et al. [7] suggested that the total chlorine concentration and metal were associated with the variation in pipeline water microbiome composition. Recent research has proposed that the system of chlorine disinfection exhibited a positive contribution in the aspect of controlling bacteria counts, but played a limited role in controlling chlorineresistant genes in bacteria [68]. Chlorination changed the structure of chlorine-resistant genes by affecting the relative abundance of chlorine-resistant genes, which enriched chlorine-resistant genes and their carriers. In the chlorination system, bacteria that could produce high extracellular polymeric substances (EPS) revealed stronger ability of survival, because EPS had a positive effect on maintaining the stability of cell adhesion structure and disinfection resistance [69]. The pipe material was found to be an important factor affecting the abundance of specific microorganisms and the bacterial community structure in DWDS [70]. Metal pipe materials and corrosion products could select bacteria that carries metal resistance genes through bacteria co-growth processes [13]. These results demonstrated that the variation in the environmental factors including temperature and chlorine attenuation caused significant variations in the bacterial community structure before and after stagnation.

\section{Conclusions}

In conclusion, this work revealed that overnight stagnation significantly increased the water temperature, and caused the deterioration of water quality during indoor heating process. Compared with fresh water, the concentration of total and intracellular ATP increased by 1.65 -fold and 1.69-fold after stagnation, respectively. Meanwhile, the number of total cell count and LNA bacteria increased significantly after stagnation, but the LNA\% was decreased. The OTUs of Pseudomonas sp., Mycobacterium sp. and Acinetobactersp. became more abundant in stagnant water and the risk of disease caused by microorganisms increased after stagnation. Network analysis indicated that the survival patterns of bacterial communities were more intricate in stagnant water. Based on SEM and RDA, temperature, residual chlorine and Fe concentration had significant correlation with bacterial community structure. In 
general, long-term disinfection of drinking water should be achieved. Continuous circulation of heattreated water in buildings is another solution to mitigate the effects of retention. This study provided theoretical supports for improving the microbial ecological structure of municipal pipelines during the heating period.

\section{Declarations}

Funding This study was funded by the National Natural Science Foundation of China (Nos. 51978561, 51979217), and the Grant from Youth Innovation Team of Shaanxi Universities in 2020 (Nos. 21JP061).

Author Contribution Xiang Liu: Investigation, Formal analysis, Writing-original draft. Haihan Zhang and Tinglin Huang: Conceptualization, Funding acquisition, Supervision. Ben Ma, Limin Niu, Kexin Zhao and Yuwei Huang: Validation, Writing-review \& editing.

Supplementary Information The online version contains supplementary material.

Data Availability The datasets generated during and/or analysed during the current study are available from the corresponding author on reasonable request.

Code Availability Not applicable.

Ethics Approval The authors declare that the work described was an original research that has not been published previously, and not under consideration for publication elsewhere, in whole or in part. The content and authorship of the submitted manuscript has been approved by all authors, and that all prevailing local, national, and international regulations and conventions, and normal scientific ethical practices, have been respected.

Consent for Publication Informed consent was obtained from all individual participants included in the study.

Conflict of Interest The authors declare that they have no known competing financial interests or personal relationships that could have appeared to influence the work reported in this paper.

\section{References}

1. Liu G, Zhang Y, Van der Mark E, Magic-Knezev A, Pinto A, Van den Bogert B, Liu W, Van der Meer W, Medema G (2018) Assessing the origin of bacteria in tap water and distribution system in an unchlorinated drinking water system by sourcetracker using microbial community fingerprints. Water Res 138:86-96. https://doi.org/10.1016/j.watres.2018.03.043

2. Zhou W, Li WY, Chen JP, Zhou Y, Wei ZQ, Gong LC (2021) Microbial diversity in full-scale water supply systems through sequencing technology: A review. Royal Soc Chem 11:25484. https://doi.org/10.1039/D1RA03680G 
3. Burleigh TD, Gierke CG, Fredj N, Boston PJ (2014) Copper tube pitting in santa Fe municipal water caused by microbial induced corrosion. Mater (Basel) 7(6):4321-4334. https://doi.org/10.3390/ma7064321

4. Tian YM, Li JX, Jia SC, Zhao WG (2021) Co-release potential and human health risk of heavy metals from galvanized steel pipe scales under stagnation conditions of drinking water. Chemosphere 267:129270. https://doi.org/10.1016/j.chemosphere.2020.129270

5. Ley CJ, Proctor CR, Singh G, Ra K, Noh Y, Odimayomi T, Salehi M, Julien R, Mitchell J, Nejadhashemi AP, Whelton AJ, Aw TG (2020) Drinking water microbiology in a water-efficient building: stagnation, seasonality, and physicochemical effects on opportunistic pathogen and total bacteria proliferation. Environ Sci Water Res Technol 6:2902-2913. https://doi.org/10.1039/d0ew00334d

6. Baron JL, Vikram A, Duda S, Stout JE, Bibby K (2014) Shift in the microbial ecology of a hospital hot water system following the introduction of an on-site monochloramine disinfection system. PLoS ONE 9:e102679. https://doi.org/10.1371/journal.pone.0102679

7. Ji P, Parks J, Edwards MA, Pruden A (2015) Impact of water chemistry, pipe material and stagnation on the building plumbing microbiome. PLoS ONE 10:e0141087.

https://doi.org/10.1371/journal.pone.0141087

8. Zhang HH, Xu L, Huang TL, Liu X, Miao YT, Liu KW, Qian XM (2021) Indoor heating triggers bacterial ecological links with tap water stagnation during winter: Novel insights into bacterial abundance, community metabolic activity and interactions. Environ Pollut 269:116094. https://doi.org/10.1016/j.envpol.2020.116094

9. Reitter C, Petzoldt H, Korth A, Schwab F, Stange C, Hambsch B, Tiehm A, Lagkouvardos I, Gescher J, Hügler M (2021) Seasonal dynamics in the number and composition of coliform bacteria in drinking water reservoirs. Sci Total Environ 787:147539. https://doi.org/10.1016/j.scitotenv.2021.147539

10. Zhang HH, Liu KW, Huang TL, Li N, Si F, Feng J, Huang X, Miao YT (2021) Effect of thermal stratification on denitrifying bacterial community in a deep drinking water reservoir. J Hydrol 596:126090. https://doi.org/10.1016/j.jhydrol.2021.126090

11. Ma B, Zhang HH, Ma ML, Huang TL, Guo HH, Yang WQ et al (2022) Nitrogen removal by two strains of aerobic denitrification actinomycetes: Denitrification capacity, carbon source metabolic ability, and raw water treatment. Bioresource Technol 344:126176.

https://doi.org/10.1016/j.biortech.2021.126176

12. Wu Y, Wang SR, Ni ZK, Li H, May LD, Pu J (2021) Emerging water pollution in the world's least disturbed lakes on Qinghai-Tibetan Plateau. Environ Pollut 272:116032. https://doi.org/10.1016/j.envpol.2020.116032

13. Kimbell LK, Wang Y, McNamara PJ (2020) The impact of metal pipe materials, corrosion products, and corrosion inhibitors on antibiotic resistance in drinking water distribution systems. Appl Microbiol Biotechnol 104:7673-7688. https://doi.org/1007/s00253-020-10777-8

14. Bian KQ, Wang C, Jia SY, Shi P, Zhang HC, Ye L, Zhou Q, Li AM (2021) Spatial dynamics of bacterial community in chlorinated drinking water distribution systems supplied with two treatment plants: An 
integral study of free-living and particle-associated bacteria. Environ Int 154:106552. https://doi.org/10.1016/j.envint.2021.106552

15. Liu G, Zhang Y, Knibbe WJ, Feng C, Liu W, Medema G, Van der Meer W (2017) Potential impacts of changing supply-water quality on drinking water distribution: A review. Water Res 116:135-148. https://doi.org/10.1016/j.watres.2017.03.031

16. Ji P, Rhoads WJ, Edwards MA, Pruden A (2017) Impact of water heater temperature setting and water use frequency on the building plumbing microbiome. ISME J 11:1318-1330. https://doi.org/10.1038/ismej.2017.14

17. Zlatanović L, Van der Hoek JP, Vreeburg JHG (2017) An experimental study on the influence of water stagnation and temperature change on water quality in a full-scale domestic drinking water system. Water Res 123:761-772. https://doi.org/10.1016/j.watres.2017.07.019

18. Zhang HH, Xu L, Huang TL, Yan MM, Liu KW, Miao YT, He HY, Li SL, Sekar R (2021) Combined effects of seasonality and stagnation on tap water quality: Changes in chemical parameters, metabolic activity and co-existence in bacterial community. J Hazard Mater 403:124018. https://doi.org/10.1016/j.jhazmat.2020.124018

19. Zhang HH, Chen SN, Huang TL, Shang PL, Yang X, Ma WX (2015) Indoor heating drives water bacterial growth and community metabolic profile changes in building tap pipes during the winter season. Int J Environ Res Public Health 12:13649-13661. https://doi.org/10.3390/ijerph121013649

20. Yoshino H, Yoshino Y, Zhang QY, Mochida A, Li NP, Li ZH, Miyasaka H (2006) Indoor thermal environment and energy saving for urban residential buildings in China. Energy and Buildings 38:1308-1319. https://doi.org/10.1016/j.enbuild.2006.04.006

21. Lane DJ, Pace B, Olsen GJ, Stahl DA, Sogin ML, Pace NR (1985) Rapid determination of 16s ribosomal RNA sequences for phylogenetic analyses. Proc Natl Acad Sci USA 82:6955-6959. https://doi.org/10.1073/pnas.82.20.6955

22. Zhang JY, Ding X, Guan R, Zhu CM, Xu C, Zhu BC, Zhang H, Xiong ZP, Xue YG, Tu J, Lu ZH (2018) Evaluation of different $16 \mathrm{~S}$ rRNA gene $\mathrm{V}$ regions for exploring bacterial diversity in a eutrophic freshwater lake. Sci Total Environ 618:1254-1267. https://doi.org/10.1016/j.scitotenv.2017.09.228

23. Ming HX, Fan JF, Liu JW, Su J, Wan ZY, Wang YT, Li DW, Li MF, Shi TT, Jin Y, Huang HL, Song JX (2021) Full-length 16S rRNA gene sequencing reveals spatiotemporal dynamics of bacterial community in a heavily polluted estuary, China. Environ Pollut 275:116567. https://doi.org/10.1016/j.envpol.2021.116567

24. Farhat N, Kim LH, Vrouwenvelder JS (2020) Online characterization of bacterial processes in drinking water systems. npj Clean Water 3:16. https://doi.org/10.1038/s41545-020-0065-7

25. Wang YY, Hammes F, De Roy K, Verstraete W, Boon N (2010) Past, present and future applications of flow cytometry in aquatic microbiology. Trends Biotechnol 28:416-424. https://doi.org/10.1016/j.tibtech.2010.04.006

26. Liu G, Van der Mark EJ, Verberk JQ, Van Dijk JC (2013) Flow cytometry total cell counts: A field study assessing microbiological water quality and growth in unchlorinated drinking water distribution 
systems. Biomed Res Int 2013:595872. https://doi.org/10.1155/2013/595872

27. Longnecker K, Sherr BF, Sherr EB (2005) Activity and phylogenetic diversity of bacterial cells with high and low nucleic acid content and electron transport system activity in an upwelling ecosystem. Appl Environ Microbiol 71:7737-7749. https://doi.org/10.1128/AEM.71.12.7737-7749.2005

28. Bouvier T, Del Giorgio PA, Gasol JM (2007) A comparative study of the cytometric characteristics of high and low nucleic-acid bacterioplankton cells from different aquatic ecosystems. Environ Microbiol. https://doi.org/10.1111/j.1462-2920.2007.01321.x. 9:2050-2066

29. Salcher MM, Pernthaler J, Posch T (2011) Seasonal bloom dynamics and ecophysiology of the freshwater sister clade of SAR11 bacteria 'that rule the waves' (LD12). ISME J 5:1242-1252. https://doi.org/10.1038/ismej.2011.8

30. Wang YY, Hammes F, Boon N, Chami M, Egli T (2009) Isolation and characterization of low nucleic acid (LNA)-content bacteria. ISME J 3:889-902. https://doi.org/10.1038/ismej.2009.46

31. Ahmad JI, Dignum M, Liu G, Medema G, Van der Hoek JP (2021) Changes in biofilm composition and microbial water quality in drinking water distribution systems by temperature increase induced through thermal energy recovery. Environ Res 194:110648. https://doi.org/10.1016/j.envres.2020.110648

32. Lehtola MJ, Laxander M, Miettinen IT, Hirvonen A, Vartiainen T, Martikainen PJ (2006) The effects of changing water flow velocity on the formation of biofilms and water quality in pilot distribution system consisting of copper or polyethylene pipes. Water Res 40:2151-2160. https://doi.org/10.1016/j.watres.2006.04.010

33. Lautenschlager K, Boon N, Wang YY, Egil T, Hammes F (2010) Overnight stagnation of drinking water in household taps induces microbial growth and changes in community composition. Water Res 44:4868-4877. https://doi.org/10.1016/j.watres.2010.07.032

34. Gabrielli M, Turolla A, Antonelli M (2021) Bacterial dynamics in drinking water distribution systems and flow cytometry monitoring scheme optimization. J Environ Manage 286:112151. https://doi.org/10.1016/j.jenvman.2021.112151

35. Hammes F, Goldschmidt F, Vital M, Wang YY, Egli T (2010) Measurement and interpretation of microbial adenosine tri-phosphate (ATP) in aquatic environments. Water Res 44:3915-3923. https://doi.org/10.1016/j.watres.2010.04.015

36. Nardini C, Devescovi V, Liu YH, Zhou XY, Lu YT, Dent JE (2016) Systemic wound healing associated with local sub-cutaneous mechanical stimulation. Sci Rep 6:39043. https://doi.org/10.1038/srep39043

37. Ban YH, Jiang YH, Li M, Zhang XL, Zhang SY, Wu Y, Xu ZY (2017) Homogenous stands of a wetland grass living in heavy metal polluted wetlands harbor diverse consortia of arbuscular mycorrhizal fungi. Chemosphere 181:699-709. https://doi.org/10.1016/j.chemosphere.2017.04.135

38. Lu YM, Zhang WL, Li Y, Zhang C, Wang LF, Niu L, Zhang HJ (2021) Microbial community shift via black carbon: Insight into biological nitrogen removal from microbial assemblage and functional patterns. Environ Res 192:110266. https://doi.org/10.1016/j.envres.2020.110266 
39. Delgado-Baquerizo M, Maestre FT, Reich PB, Jeffries TC, Gaitan JJ, Encinar D, Berdugo M, Campbell CD, Singh BK (2016) Microbial diversity drives multifunctionality in terrestrial ecosystems. Nat Commun 7:10541. https://doi.org/10541.10.1038/ncomms10541

40. Nguyen C, Elfland C, Edwards M (2012) Impact of advanced water conservation features and new copper pipe on rapid chloramine decay and microbial regrowth. Water Res 46:611-621. https://doi.org/10.1016/j.watres.2011.11.006

41. Bautista-de Los Santos QM, Chavarria KA, Nelson KL (2019) Understanding the impacts of intermittent supply on the drinking water microbiome. Curr Opin Biotechnol 57:167-174. https://doi.org/10.1016/j.copbio.2019.04.003

42. Masters S, Wang H, Pruden A, Edwards MA (2015) Redox gradients in distribution systems influence water quality, corrosion, and microbial ecology. Water Res 68:140-149. https://doi.org/10.1016/j.watres.2014.09.048

43. Alfredo K (2021) The "Burn": water quality and microbiological impacts related to limited free chlorine disinfection periods in a chloramine system. Water Res 197:117044. https://doi.org/10.1016/j.watres.2021.117044

44. Li M, Wang Y, Liu Z, Sha Y, Korshin GV, Chen Y (2020) Metal-release potential from iron corrosion scales under stagnant and active flow, and varying water quality conditions. Water Res 175:115675. https://doi.org/10.1016/j.watres.2020.115675

45. Wang JY, Yan HX, Xin KL, Tao T (2020) Risk assessment methodology for iron stability under water quality factors based on fuzzy comprehensive evaluation. Environ Sci Eur 32:81. https://doi.org/10.1186/s12302-020-00356-z

46. Prest El, Hammes F, Van Loosdrecht MCM, Vrouwenvelder JS (2016) Biological stability of drinking water: Controlling factors, methods, and challenges. Front Microbiol 7:45. https://doi.org/10.3389/fmicb.2016.00045

47. Ndiongue S, Huck PM, Slawson RM (2005) Effects of temperature and biodegradable organic matter on control of biofilms by free chlorine in a model drinking water distribution system. Water Res 39:953-964. https://doi.org/10.1016/j.watres.2004.12.019

48. Hammes F, Broger T, Weilenmann HU, Vital M, Helbing J, Bosshart U, Huber P, Odermatt RP, Sonnleitner B (2012) Development and laboratory-scale testing of a fully automated online flow cytometer for drinking water analysis. Cytometry A 81:508-516. https://doi.org/10.1002/cyto.a.22048

49. Ling F, Whitaker R, LeChevallier MW, Liu WT (2018) Drinking water microbiome assembly induced by water stagnation. ISME J 12:1520-1531. https://doi.org/10.1038/s41396-018-0101-5

50. Yang X, Huang TL, Zhang HH (2015) Effects of seasonal thermal stratification on the functional diversity and composition of the microbial community in a drinking water reservoir. Water 7:55255546. https://doi.org/10.3390/w7105525

51. Douterelo I, Sharpe RL, Boxall JB (2013) Influence of hydraulic regimes on bacterial community structure and composition in an experimental drinking water distribution system. Water Res 47:503- 
516. https://doi.org/10.1016/j.watres.2012.09.053

52. Furuhata K, Ishizaki N, Fukuyama M (2015) Bacterial contamination in cold water samples obtained from water dispensers. Biocontrol Sci 20:147-151. https://doi.org/10.4265/bio.20.147

53. Woo PCY, Wong SSY, Yuen KY (2002) Ralstonia pickettii bacteraemia in a cord blood transplant recipient. New Microbiol 25:97-102. https://doi.org/10.1006/mpat.2001.0479

54. Zhang ML, Xu MY, Xu SF, Zhang LY, Lin K, Zhang L, Bai M, Zhang C, Zhou H (2020) Response of the bacterial community and antibiotic resistance in overnight stagnant water from a municipal pipeline. Int J Environ Res Public Health 17:1995. https://doi.org/10.3390/ijerph17061995

55. Carvalheira A, Silva J, Teixeira P (2021) Acinetobacter spp. in food and drinking water - A review. Food Microbiol 95:103675. https://doi.org/10.1016/j.fm.2020.103675

56. Perrin Y, Bouchon D, Delafont V, Moulin L, Héchard Y (2019) Microbiome of drinking water: A fullscale spatio-temporal study to monitor water quality in the paris distribution system. Water Res 149:375-385. https://doi.org/10.1016/j.watres.2018.11.013

57. Stanish LF, Hull NM, Robertson CE, Harris JK, Stevens MJ, Spear JR, Pace NR (2016) Factors influencing bacterial diversity and community composition in municipal drinking waters in the ohio river basin, USA. PLoS ONE 11:e0157966. https://doi.org/10.1371/journal.pone.0157966

58. Li WY, Tan QW, Zhou W, Chen JP, Li Y, Wang F, Zhang JP (2020) Impact of substrate material and chlorine/chloramine on the composition and function of a young biofilm microbial community as revealed by high-throughput 16S rRNA sequencing. Chemosphere 242:125310.

https://doi.org/10.1016/j.chemosphere.2019.125310

59. Falkinham âçJO (2020) Living with legionella and other waterborne pathogens. Microorganisms. https://doi.org/10.3390/microorganisms8122026. 8:2026

60. Chen J, Shi Y, Cheng DQ, Jin Y, Hutchins W, Liu JQ (2019) Survey of pathogenic bacteria of biofilms in a metropolitan drinking water distribution system. FEMS Microbiol Lett 366:fnz225. https://doi.org/10.1093/femsle/fnz225

61. Lennon JT, Locey KJ (2020) More support for earth's massive microbiome. Biology Direct 15:5. https://doi.org/10.1186/s13062-020-00261-8

62. Xia Y, Wen XH, Zhang B, Yang YF (2018) Diversity and assembly patterns of activated sludge microbial communities: A review. Biotechnol Adv 36:1038-1047. https://doi.org/10.1016/j.biotechadv.2018.03.005

63. Volkov I, Banavar JR, Hubbell SP, Maritan A (2003) Neutraltheory and relative species abundance in ecology. Nature 424:1035-1037. https://doi.org/10.1038/nature01883

64. Zhang HH, Zong RR, He HY, Huang TL (2022) Effects of hydrogen peroxide on Scenedesmus obliquus: Cell growth, antioxidant enzyme activity and intracellular protein fingerprinting. Chemosphere 287:132185. https://doi.org/10.1016/j.chemosphere.2021.132185

65. Douterelo I, Dutilh BE, Arkhipova K, Calero C, Husband S (2020) Microbial diversity, ecological networks and functional traits associated to materials used in drinking water distribution systems. Water Res 173:115586. https://doi.org/10.1016/j.watres.2020.115586 
66. Aqeel H, Basuvaraj M, Hall M, Neufeld JD, Liss SN (2016) Microbial dynamics and properties of aerobic granules developed in a laboratory-scale sequencing batch reactor with an intermediate filamentous bulking stage. Appl Microbiol Biotechnol 100:447-460. https://doi.org/10.1007/s00253015-6981-7

67. Krick A, Kehraus S, Eberl L, Riedel K, Anke H, Kaesler I, Graeber I, Szewzyk U, König GM (2007) A marine Mesorhizobium sp. produces structurally novel long-chain n-acyl-I-homoserine lactones. Appl Environ Microbiol 73:3587-3594. https://doi.org/10.1128/AEM.02344-06

68. Wan K, Lin WF, Zhu S, Zhang SH, Yu X (2019) Biofiltration and disinfection codetermine the bacterial antibiotic resistome in drinking water: A review and meta-analysis. Front Environ Sci Eng 14:10. https://doi.org/10.1007/s11783-019-1189-1

69. Zhu ZB, Shan LL, Zhang XY, Hu FP, Zhong D, Yuan YX, Zhang J (2021) Effects of bacterial community composition and structure in drinking water distribution systems on biofilm formation and chlorine resistance. Chemosphere 264:128410.

https://doi.org/10.1016/j.chemosphere.2020.128410

70. Learbuch KLG, Smidt H, Van der Wielen PWJJ (2021) Influence of pipe materials on the microbial community in unchlorinated drinking water and biofilm. Water Res 194:116922. https://doi.org/10.1016/j.watres.2021.116922

\section{Figures}



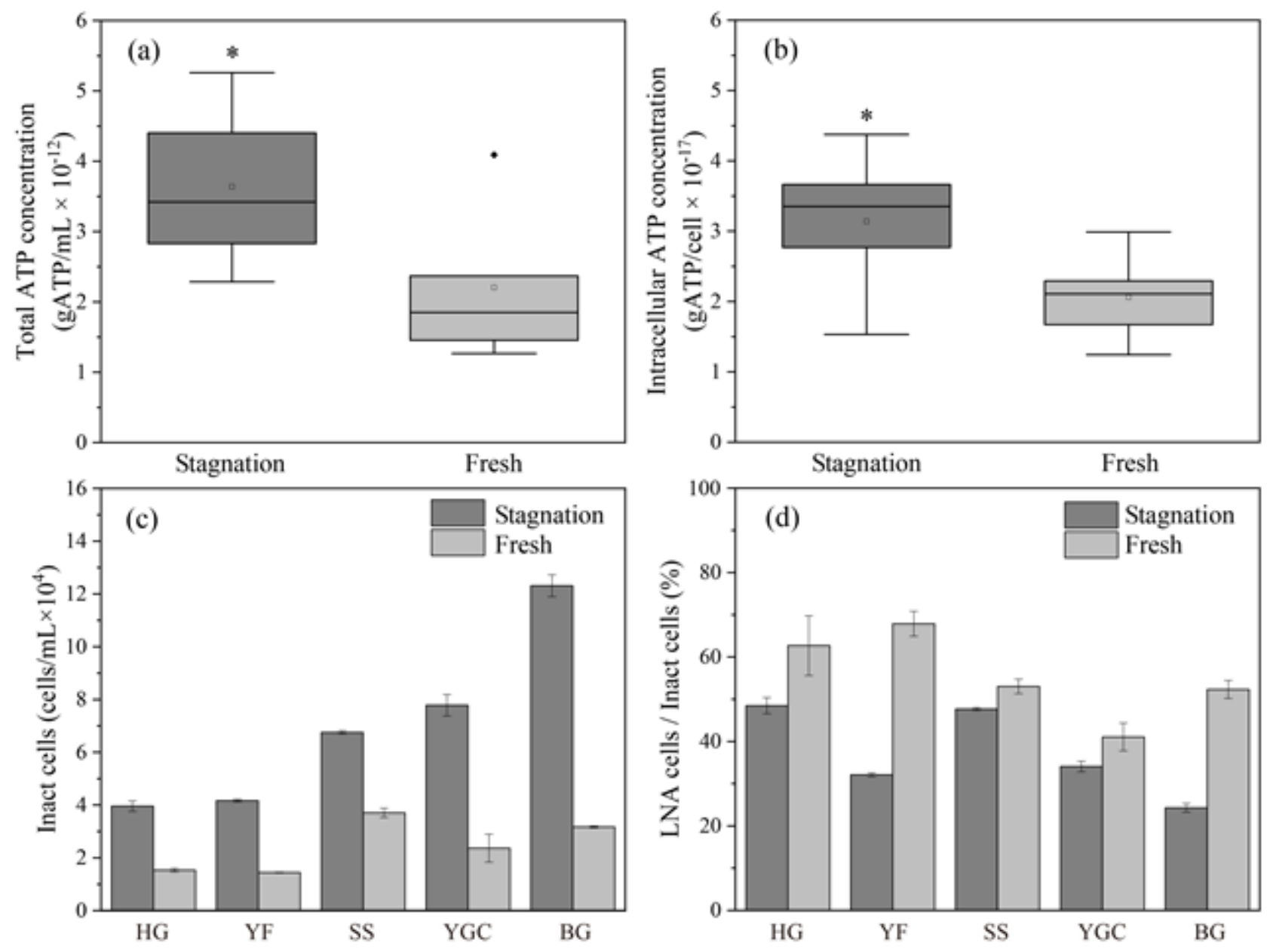

Figure 1

Boxplot of (a) total ATP and (b) intracellular ATP concentrations in stagnant water and fresh water. Bar diagram of (c) intact cells concentrations and (d) LNA cells/intact cells ratio (LNA\%) in each stagnant water and fresh water. Each Bar diagram was based on water samples collected from 5 taps. Every measurement conducted triplicates. 


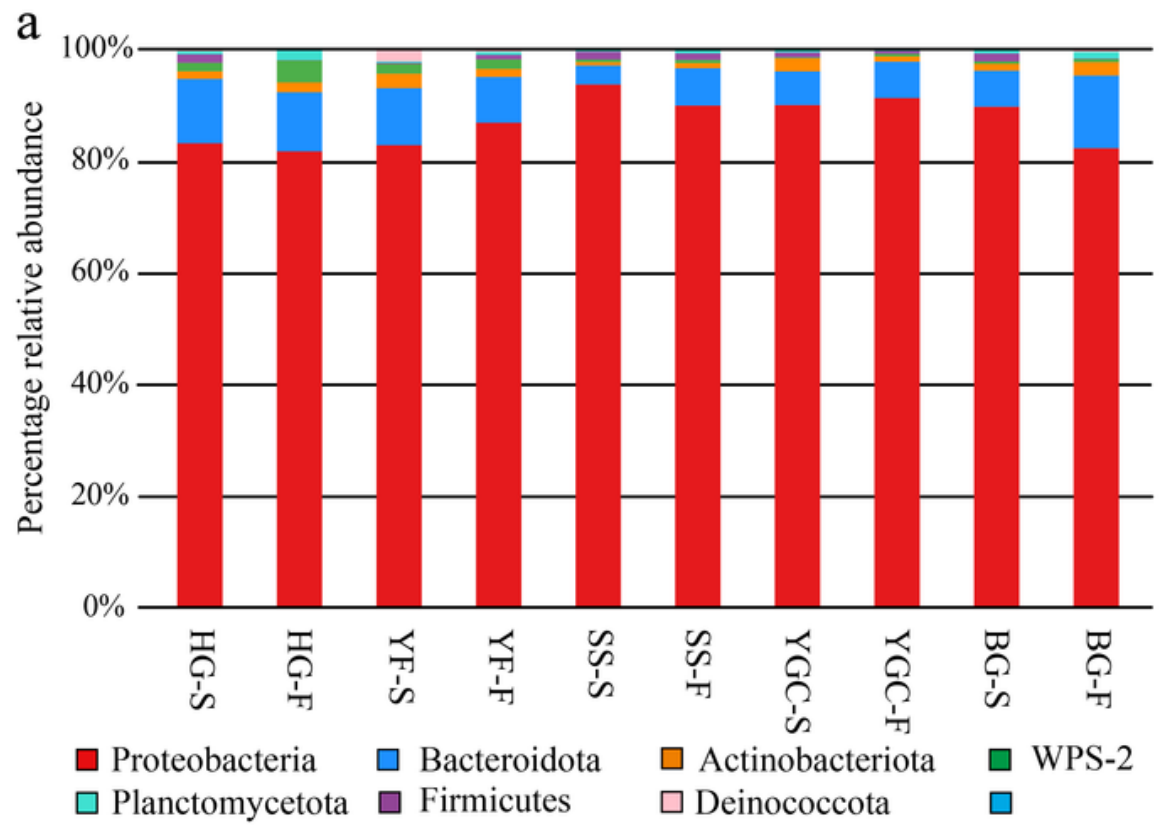

b

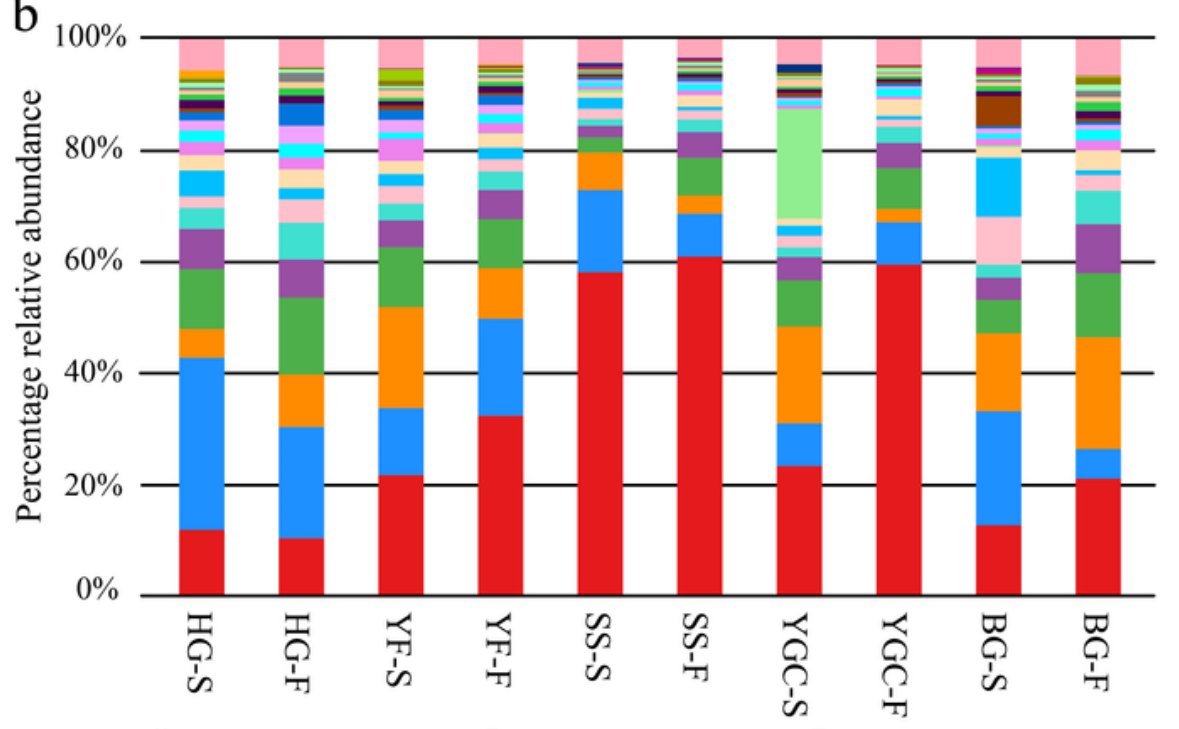
$\square$ Curvibacter
$\square$ Ralstonia
口 Paraburkholderia
$\square$ Bradyrhizobium
- Vibrionimonas
$\square$ Mesorhizobium
$\square$ Phreatobacter
$\square$ Sphingomonas
$\square$ Methylovirgula
$\square$ Acinetobacter
$\square$ Mucilaginibacter
$\square$ Phyllobacterium
$\square$ Coxiella
- WPS-2 norank
- Hyphomicrobium
- Variovorax
$\square$ Rhodanobacter
$\square$ Mycobacterium
$\square$ Microbacterium
$\square$ Chitinophaga
- Gemmataceae_uncultured
$\square$ Deinococcus
- Staphylococcus
- Insolitispirillum
$\square$ Bacillus
$\square$ Others

\section{Figure 2}

The microbial community composition in stagnant water and fresh water at (a) phylum level and (b) genus level (S: stagnant sample, F: fresh sample). 

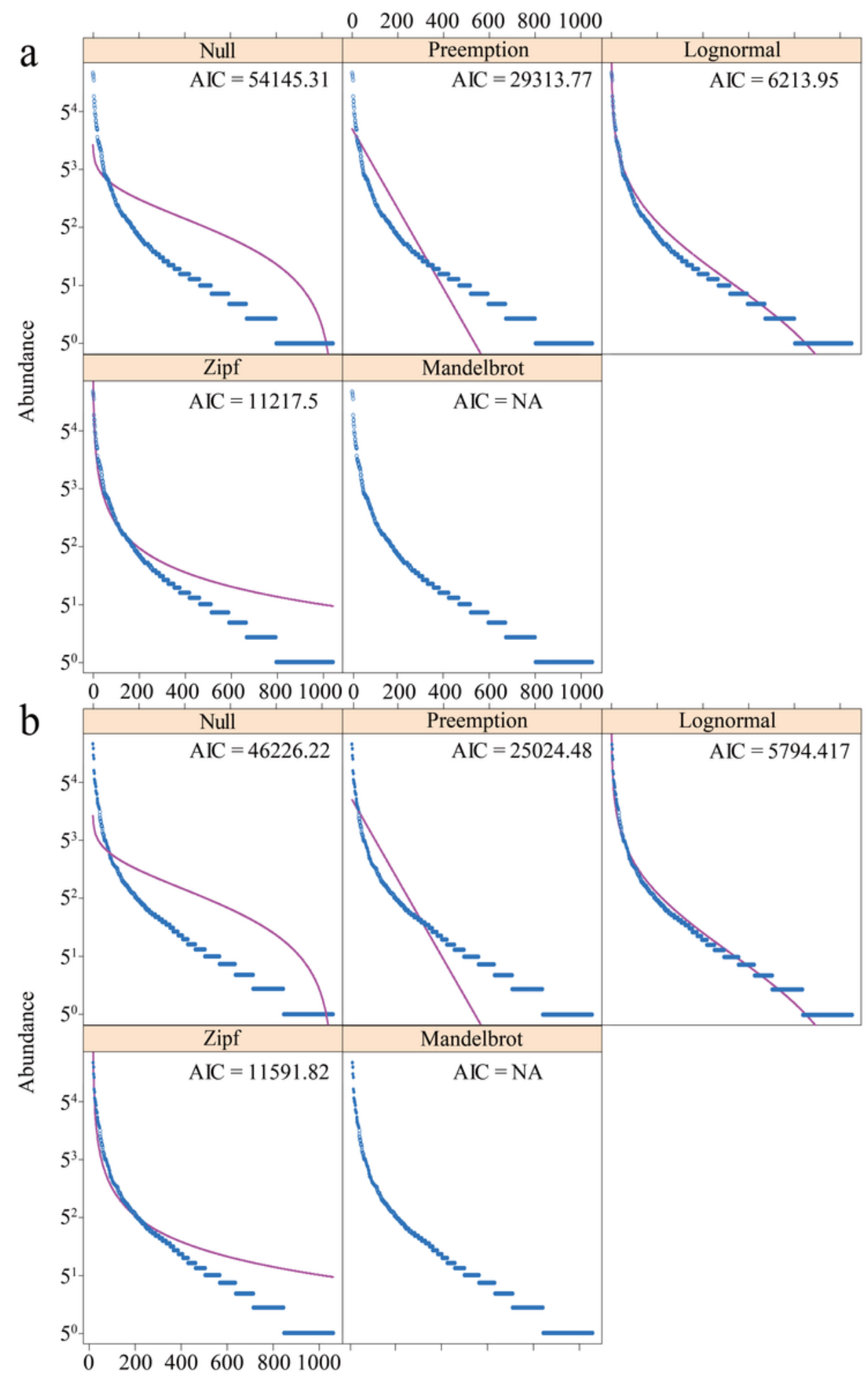

\section{Figure 3}

Statistical comparison of the fit of basic SAD models from (a) stagnant water and (b) fresh water. Akaike's Information Criterion (AIC) and model fits for several basic SAD models, including the broken stick (null model), preemption, lognormal, Zipf, and Zipf-Mandelbrot models. AIC (lower is better) explains that the preemption model is the best fit. 


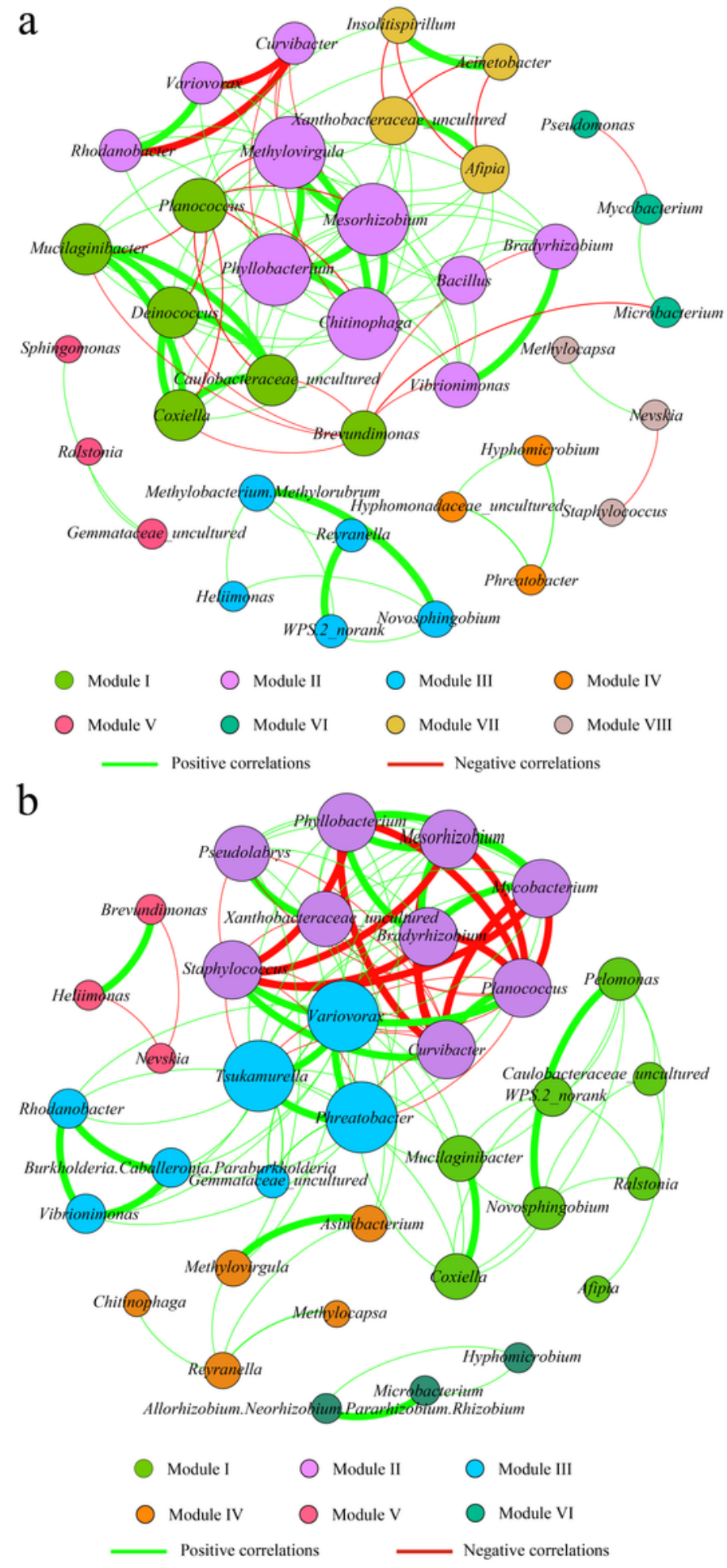

\section{Figure 4}

Network analysis based on the correlation analysis of bacterial community from (a) stagnant water and (b) fresh water. Red lines represent negative correlations, and green lines represent positive correlations. The correlation coefficients visualized by the size of the line. The size of each node is proportional to the number of connections (degree). 


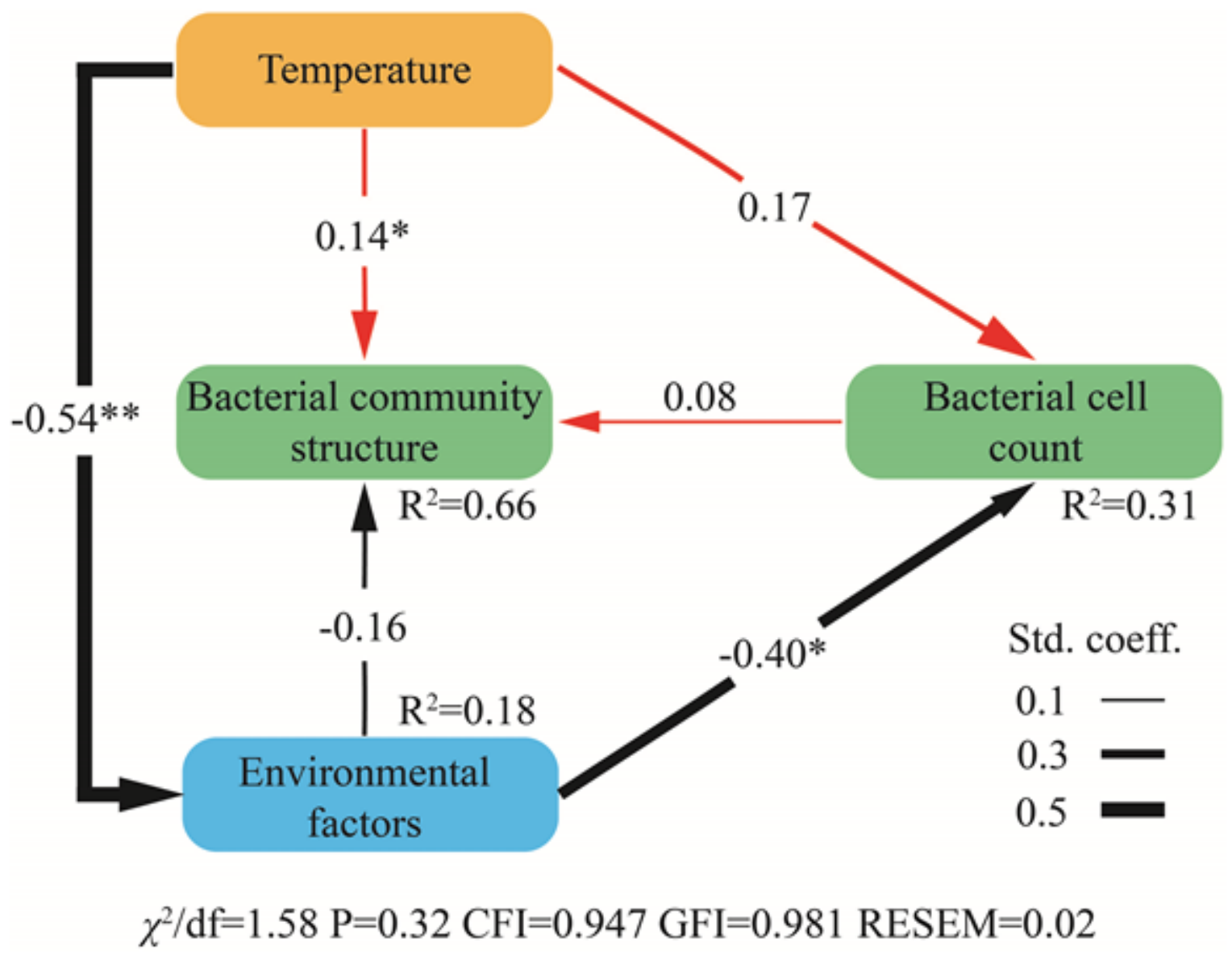

Figure 5

Structural equation modelling (SEM) to analyze the relationship among temperature, environmental factors, bacterial community structure and bacterial cell count.Red and black arrows show the positive and negative relationships, respectively. The number next to the arrows represent the normalized path coefficients (Std. coeff). $R^{2}$ values represent the proportion of the variance explained. The root means square error of approximation and $\chi^{2}$ test was used to assess regression model fit. ${ }^{\star} P<0.05,{ }^{\star} P<0.01$. 


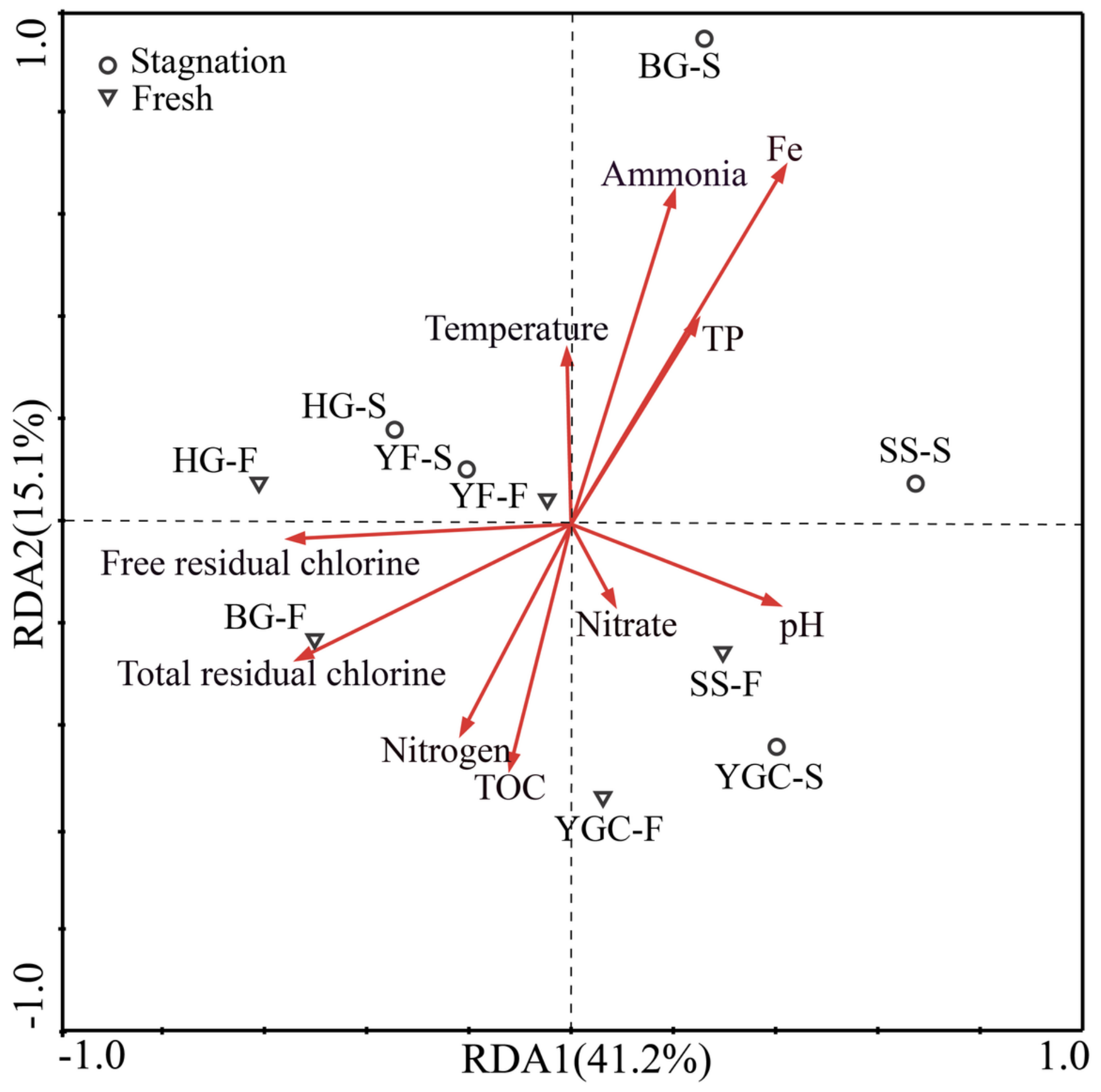

Figure 6

Redundancy analysis (RDA) to reveal the relationship between environmental parameters and bacterial community structure (at genus level) in 5 taps. RDA1 explained $41.2 \%$ and RDA2 explained $15.1 \%$ of the total variance, respectively.

\section{Supplementary Files}


This is a list of supplementary files associated with this preprint. Click to download.

- 6.SupplementaryMaterials.doc 